\title{
The Impact of Foreign Direct Investment on Financial Market Development: The Case of Jordan
}

\author{
Buthiena Kharabsheh ${ }^{1} \&$ Ahlam Aldaher ${ }^{1}$ \\ ${ }^{1}$ Department of Finance and Banking Sciences, Faculty of Economics and Administrative Sciences, Yarmouk \\ University, Jordan \\ Correspondence: Buthiena Kharabsheh, Assistant Professor, Department of Finance and Banking Sciences, Faculty \\ of Economics and Administrative Sciences, Yarmouk University, Jordan.
}

Received: December 29, 2019

Accepted: January 31, 2020

Online Published: June 28, 2020

doi:10.5430/ijfr.v11n4p64

URL: https://doi.org/10.5430/ijfr.v11n4p64

\begin{abstract}
This study examines the causal effect between foreign direct investment (FDI) and financial market development (FMD) in Jordan. Annual time-series data is used over the period 1978-2017. Principal component analysis is employed to create two indices to reflect FMD, namely stock market development (SMD) and banking sector development (BSD). To detect the causal effect between FDI and FMD, Vector Autoregressive Regressions, Granger Causality test and Johansen Co-integration test are employed in the analysis. In the short-run, the findings of Vector Autoregressive Regressions document a positive significant effect between SMD and FDI, however, no effect is found between BSD and FDI. The Granger Causality test shows unidirectional causality between SMD to FDI. Moreover, the Johansen Co-integration test reveals a long-run equilibrium relationship between FDI and FMD. These results are expected to have important implications for policy makers in Jordan.
\end{abstract}

Keywords: foreign direct investment, stock market development, banking sector development, causality, Jordan

\section{Introduction}

Foreign direct investment (FDI) is defined as investments outside the investors' border. FDIs commonly aim to create a long-lasting interest in the targeted country (Malcus \& Persson, 2018). To achieve this long lasting objective, at least $10 \%$ of the voting power should be held by the investor otherwise it is considered as portfolio investment (OECD, 2008). In developing countries, foreign direct investment is one of the main sources of capital inflow since these countries generally suffer particularly from limited capital, and in most cases this available capital is invested in low risk investments. The inflow of FDI is a partial solution of the problem because it is not simply transfer of capital, but also involves transfer of new technology as well as managerial skills, in addition to encouraging domestic capital to engage in higher risk/profit investments. Overall, increased FDI inflow leads to higher production level, more innovative investments and higher economic growth (Chen, 1992; Sultana \& Pardhasaradhi, 2012).

During 1995 and 2005 the Jordanian economy benefitted from high FDI inflow, particularly from Gulf countries, encouraged by a number of incentive factors including the Kingdom's political stability, particularly in comparison with other areas in the region. Jordan's strategic geographic location in addition to wide-ranging international relations through, for example, the EU, IMF etc., enable it to receive international financial, political and logistical support, aided by an excellent reputation for its well-educated human resources. However, in the aftermath of the recent financial crisis followed by severe political instability in Iraq, Syria and Palestine, there was a noticeable decrease in FDI inflow which prompted a number of remedial actions by the Jordanian government, as incentives to stimulate foreign investment. These inducements included the government-established Qualified Industrial Zone (QIZ) in addition to Aqaba Free Zone, offering very attractive tax concessions to foreign companies and enterprises, in addition to revising and simplifying registration procedures required for foreign companies. An economic upturn began at the beginning of 2017 where the FDI increased to approximately 2 billion USD, showing a 7\% growth rate (UNCTAD, 2019) (Note 1).

Figure 1 shows the FDI inflow to Jordan during the period 1978 -2017, and Table 1 presents the top five sources of FDI inflow to the Jordanian economy. As mentioned above, the Gulf countries are the main providers of FDI. Recently, the link between foreign direct investment (FDI) and financial market development (FMD) has attracted the attention of researchers, practitioners and policymakers, previous literature indicating indirect study of these two 
variables, including several papers examining the relationship between financial market development and economic growth.

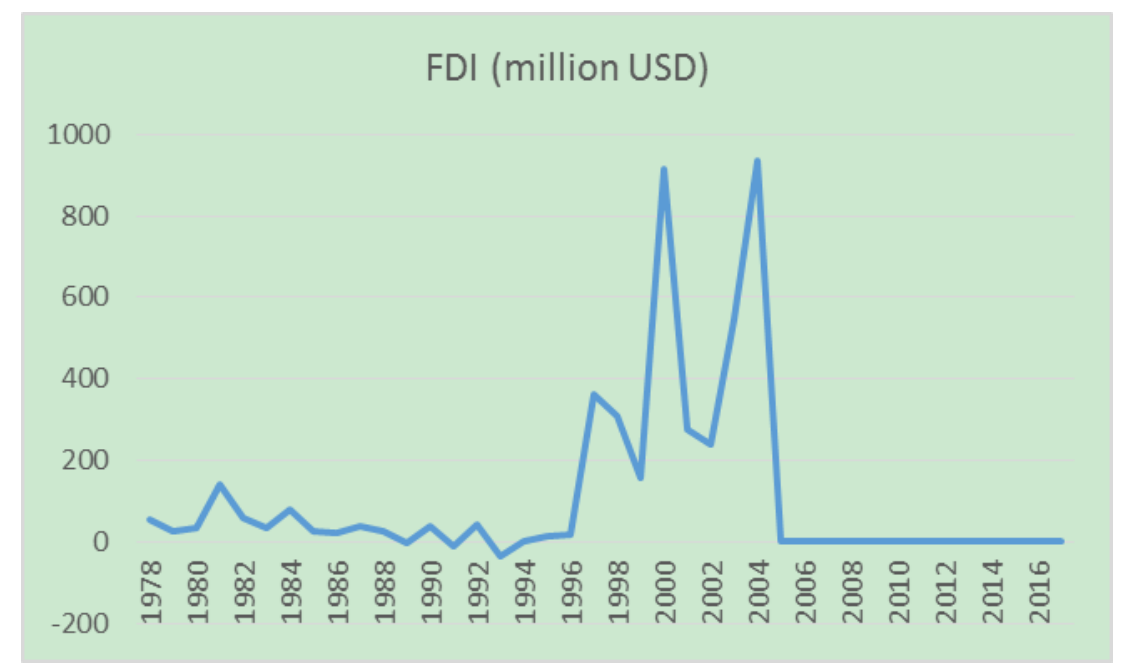

Figure 1. FDI inflow during the study period (1978-2017)

Table 1. Top five sources of FDI (US Dollars, Millions)

\begin{tabular}{lll}
\hline Total Inward & Amount & $100 \%$ \\
\hline Saudi Arabia & 3,783 & $18.1 \%$ \\
\hline Kuwait & 3,239 & $15.5 \%$ \\
\hline United States & 1,647 & $7.9 \%$ \\
\hline United Arab Emirates & 1,616 & $7.7 \%$ \\
\hline Iraq & 1,479 & $7.1 \%$ \\
\hline
\end{tabular}

Source: http://data.imf.org/?sk=40313609-F037-48C1-84B1-E1F1CE54D6D5\&sId=1482186404325 (Statistics based on data from the last economic survey including FDI, carried out in 2009).

The majority of these papers document a positive association between the two variables see for example (Levine and Zervos, 1996; Korgaonkar, 2012 and Nazir, Nawaz, Anwar\& Ahmed, 2010). Boubakari and Jin (2010) provide evidence that more developed, active and highly liquid markets positively spur economic growth, whereas Nazir et al. (2010) find that stock market development positively enhanced economic growth in Pakistan. Korgaonkar (2012) highlights the importance of the development in the stock market for the host country, the author arguing that FDI will positively affect economic growth only if the stock market is developed, opening another line of research to test the effect of FDI on economic growth. Domarchi and Nkengapa (2007) report a positive association between FDI and economic growth, similarly, Hermes and Lensink (2003) and Alfaro, Chanda, Ozcan and Sayek (2010) among others, show that FDI positively boosts economic growth. The findings of these papers illustrate that this positive effect of FDI is an important source not only of capital but also technology and skills.

The empirical evidence on the direct link between foreign direct investment (FDI) and financial market development (FMD) is limited, very few papers investigating the impact of FDI on FMD. In the literature, FMD is reflected by two factors, namely (SMD) and (BSD) (Naceur \& Ghazouani, 2007; Kar, Nazlioglu, \& Agir, 2011). The importance of this topic is inherent in the fact that a developed financial market in terms of stock market and banking sector directly simulates economic growth. The number of listed firms, their market capitalization and traded shares increase when the market is more developed (Jeffus, 2004). Likewise, development in the banking sector leads to higher efficiency in the financial system. Effectiveness in the financial system implies enhancement in return, liquidity and access to capital. However, the argument that these developments in FMD attract more FDI must be questioned empirically. In other words, well-functioning markets lead to higher FDI inflows, although the opposite 
may also be true. The inflow of FDI improves the efficiency of both stock market and banking sector. FDI is not only capital transfer, but also technology and labour skills (Adam \& Tweneboah, 2008; Tsagkanos, Siriopoulos, \& Vartholomatou, 2018).

Accordingly, this paper aims to test the dynamic causal effect between the FDI and FMD in Jordan over the period 1978-2017. This study uses several proxies to create two indices using principal component analysis; one for SMD and the other for BSD. Vector Autoregressive Regressions and Granger causality test in addition to the Johansen System Cointegration test are used to determine the nature of this relationship. This paper is motivated by the limited work on the causal effect between FDI and FMD. Providing empirical evidence on such relationships and using up-to-date data from a developing country like Jordan is expected to contribute to the existing economic literature. Furthermore, these findings are expected to have important implications for policy makers.

The remainder of this paper is structured as follows: Section 2 provides the relevant literature review and hypotheses development; Section 3 presents the data, study variables and the methodology, while the empirical results are presented in section 4; the final section concludes the paper.

\section{Literature Review and Hypotheses Development}

The theoretical background in this study is mainly based on the modern portfolio theory developed by Harry Markowitz in 1952. This theory provides explanations for investor motivation to seek foreign investments. The modern portfolio theory assumes that investors are risk averse, so for a certain level of risk, investors look for the highest return. The theory argues that investors should diversify their investments whereby instead of concentrating the whole wealth in a single risky asset, the wealth should be divided and diversified into several assets. Building on modern portfolio theory, Bodie, Kane and Marcus (2014) argue that investors try to invest in assets outside their border i.e., international diversification to minimize risk. In line with these arguments, Claessens and Rhee (1993) propose that foreign investments have a positive influence, raising efficiency with a long-term influence on domestic financial markets.

Prior literature that links FDI and financial market development commonly supports two views: The first concludes that higher inflows of FDI increase capital availability in the domestic economy and positively affect financial markets and banking sector development (Desai, Foley\& Hines, 2006; Alfaro et al, 2010; Hermes \& Lensink, 2003), while the second view finds that active financial markets or market liberalization can be viewed as an attractive opportunity for foreign investors. A well-functioning financial market means higher liquidity that may result in lower cost of capital and thus attract more foreign investments (Al Nasser \& Soydemir, 2010; Bekaert, Harvey \& Lundblad, 2004; Levine et al., 2000).

The causal relationship between financial market development and FDI is documented in several papers. For instance, Adam and Tweneboah (2008) test the relationship between FDI and Ghana's stock market development, with the findings revealing that FDI had a significant, positive effect on stock market development in Ghana. Al Nasser and Soydemir (2010) examine the link between FDI and financial development in 14 Latin American countries, results indicating that a well-developed market is a fundamental determinant of FDI level. The causality tests in the study show only a unidirectional effect from banking sector development to FDI, but a bidirectional effect between stock market development and FDI. The results suggest that FDI improve stock market development and as a result, stock market development attracts higher FDI.

Abdul Malik and Amjad (2013) investigate the impact of FDI on the SMD in Pakistan, for the period 1985-2011. Johansen co-integration approach and Granger Causality test were applied to check the causality relationship. The findings reveal that FDI has a positive role in boosting the aggregate SMD in the long-run. Further, a bi-directional causality between FDI and economic growth is documented. However, the study finds unidirectional causality between aggregate SMD and economic growth. Raza, Jawaid, Afshan, and Abd Karim (2015) provide further evidence from Pakistan using annual series data from 1976-2011. The study uses Autoregressive Distributed Lag Bound, Error Correction Model and rolling window in the estimation method. The results indicate that FDI, worker remittances and economic growth have a significant positive relation with the SMD in both the long and short-run bi-directional causal relationship of FDI and economic growth with stock market capitalization, while a unidirectional causal relationship is found between workers' remittances and stock market capitalization.

Recently, Malcus and Persson (2018) provide evidence from Sweden using time series regression analysis of quarterly data from 1982-2017. The study examines the impact of FDI on SMD in addition to various macroeconomic controls. Affärsvärlden General Index (AFGX) is used as a proxy of SMD and net inflow FDI as a proxy of FDI. The study reports only weak contemporaneous relationship between FDI and SMD. However, in the 
short-run, FDI significantly and negatively affects SMD, which implies that FDI may be considered as a substitute for the SMD. Tsagkanos et al. (2018) study the relationship between SMD and FDI in Greece through the period 1988-2014. Two periods were created; the first from 1988-2001 where the Greek market ranked as an emerging market, and the second from 2001-2014 where the Greek market ranked as a developed market. The Johansen co-integration approach and Granger Causality test were applied to check the symmetric long run relationship. The results show a weak positive relationship for the full period examined, however, in the first sub period the relationship is strong and no significant effect is found in the second sub period.

This study aims to test the causal effect between FDI and financial market development (FMD). Two proxies are used for FMD, the first is stock market development (SMD) and the second is related to the banking sector development (BSD). To achieve this objective, the following hypotheses are tested.

$\mathrm{H}_{1 \mathrm{~A}}$ : SMD Granger-causes FDI.

$\mathrm{H}_{1 \mathrm{~B}}$ : FDI Granger-causes SMD.

$\mathrm{H}_{2 \mathrm{~A}}$ : BSD Granger-causes FDI.

$\mathrm{H}_{2 \mathrm{~B}}$ : FDI Granger-causes BSD.

\section{Data, Study Variables and Methodology}

This study employs annual time series data for the period 1978-2017. The data were mainly extracted from three sources: (1) World Development Indicators, provided by the World Bank, (2) Amman Stock Exchange website and (3) UNCTAD database. The focus of this study is to investigate the nature of the relationship between foreign direct investment (FDI) and financial market development (FMD).

FMD is reflected by two measures, stock market development (SMD) and banking sector development (BSD). The first variable of interest is stock market development (SMD). The definition of SMD includes the advancements in terms of the quantity and quality of stock market services. SMD involves the interaction of several factors and activities, so it is difficult to use only a single measure (Cheng, 2012;Cooray, 2010; Darrat, Elkhal \& McCallum, 2006; Hou \& Cheng, 2010; Kar et al., 2011; Kolapo \& Adaramola, 2012; Pradhan et al., 2013ª). In line with the literature, this study selects four variables to reflect the stock market development, namely the change in the stock market index, turnover ratio, traded stocks and the number of listed companies.

Banking sector development (BSD) is related to the advancements in terms of the quantity and quality of banking services. Similar to SMD, it is difficult capture this definition using only a single measure, since this process is a combination of the interaction of different factors (Banos, Crouzille, Nys, \& Sauviat, 2011; Gregorio \& Guidotti, 1995; Gries, Kraft \& Meierrieks, 2009; Pradhan et al., 2013 ). To reflect banking sector development, this study uses domestic credit provided by the banking sector calculated as a percentage of GDP, domestic credit to the private sector calculated as a percentage of GDP, and broad money supply calculated as a percentage of GDP. SMD and BSD measures are in line with (Pradhan et al., 2014; Cherif \& Dreger, 2016; and Malcus \& Persson, 2018). For both SMD and BSD, this study employs principal component analysis to extract composite indices for both measures using the variables described above (Note 2).

FDI is measured as the net foreign direct investment inflow. The values of FDI extracted using UNCTAD database. Several macroeconomic variables were included since these variables might affect the relationship between FDM and FDI. Using the World Bank indicators, the following variables are included: GDP growth is measured as the annual percentage change in the gross domestic product, inflation is measured as the annual percentage change in consumer price index, net household savings and exchange rate.

The study initially tests the dynamic short-run effect of FDI on FMD using vector autoregressive regression (VAR) as follows:

$$
\begin{aligned}
& \mathrm{SMD}_{\mathrm{t}}=\alpha+\phi_{1} \mathrm{SMD}_{\mathrm{t}-1}+. .+\phi_{\mathrm{p}} \mathrm{SMD}_{\mathrm{t}-\mathrm{p}}+\beta_{1} \mathrm{FDI}_{\mathrm{t}-1}+. .+\beta_{\mathrm{p}} \mathrm{FDI}_{\mathrm{t}-\mathrm{p}}+\delta 1 \mathrm{MAC}_{\mathrm{t}-1}+. .+\delta_{\mathrm{p}} \mathrm{MAC}_{\mathrm{t}-\mathrm{p}}+\varepsilon_{\mathrm{t}} \\
& \mathrm{BSD}_{\mathrm{t}}=\alpha+\phi_{1} \mathrm{BSD}_{\mathrm{t}-1}+. .+\phi_{\mathrm{p}} \mathrm{BSD}_{\mathrm{t}-\mathrm{p}}+\beta_{1} \mathrm{FDI}_{\mathrm{t}-1}+. .+\beta_{\mathrm{p}} \mathrm{FDI}_{\mathrm{t}-\mathrm{p}}+\delta 1 \mathrm{MAC}_{\mathrm{t}-1}+. .+\delta_{\mathrm{p}} \mathrm{MAC}_{\mathrm{t}-\mathrm{p}}+\varepsilon_{\mathrm{t}}
\end{aligned}
$$

Where SMD is stock market development; FDI is foreign direct investment; MAC is a vector of macroeconomic variables that include GDP growth, inflation, net household savings and exchange rate; $p$ is the number of lags. In this study, Akaike Information Criteria is used to specify the number of lags in the VAR estimation, where the number of lags in this study is found to be 2. The second equation is similar to the first one except using BSD (banking sector development), the second proxy of FMD.

Based on the VAR estimation, the Granger causality tests are conducted as follows: 


$$
\begin{aligned}
\mathrm{SMD}_{\mathrm{t}} & =\alpha_{1}+\sum \beta_{i} F D I_{t-i}+\sum \lambda_{k} S M D_{t-k}+\varepsilon_{t} \\
\mathrm{FDI}_{\mathrm{t}} & =\alpha_{2}+\sum \gamma_{i} S M D_{t-i}+\sum \theta_{k} F D I_{t-k}+\varepsilon_{t}^{\prime}
\end{aligned}
$$

The same equations above are repeated for BSD.

In line with the literature, the long-run relationship between FMD and FDI has been investigated using Johansen System Cointegration test (Johansen, 1988). The null hypothesis tested $\left(\mathrm{H}_{0}: \mathrm{r}=0\right)$ of no Cointegration. In the Johansen System Cointegration test, two likelihood ratios are tested, namely the maximum eigenvalue test and the trace test. The Maximum Eigenvalue test conducts tests on each eigenvalue separately. It tests the null hypothesis that the number of co-integrating vectors is equal to $r$ contrary to the alternative of $r+1$ co-integrating vectors (Brooks, 2008).

$$
\begin{gathered}
\lambda_{\text {Trace }}(\mathrm{r})=-\mathrm{T} \sum_{i=r+1}^{p} \ln (1-\lambda i) \\
\lambda_{\max }(\mathrm{r}, \mathrm{r}+1)=-\mathrm{T} \ln \left(1-\lambda_{\mathrm{r}+1}\right)
\end{gathered}
$$

Where: $\lambda_{\text {Trace }}$ is the Trace Test. $\lambda_{\max }$ is the Maximum Eigen Value Test. $r$ is the number of Cointegration vectors. $\lambda_{\mathrm{i}}$ is the $\mathrm{i}^{\text {th }}$ ordered eigenvalue.

\section{Empirical Results and Discussion}

Table 2 presents the mean value of all the variables used in the analysis in addition to the unit root test results. The augmented Dickey-Fuller test is used to check for stationarity. The null hypothesis is that the variable has a unit root,

\begin{tabular}{|c|c|c|c|}
\hline Variable & Mean value & & $1^{\text {st }}$ Diff \\
\hline \multirow[t]{2}{*}{ SMD } & \multirow{2}{*}{-0.38} & Intercept & $-1.99 * * *$ \\
\hline & & Intercept and Trend & $-5.69 * * *$ \\
\hline \multirow[t]{2}{*}{ BSD } & \multirow{2}{*}{0.21} & Intercept & $-2.09 * * *$ \\
\hline & & Intercept and Trend & $-6.41 * * *$ \\
\hline \multirow[t]{2}{*}{ FDI(Millions ) } & \multirow{2}{*}{160.74} & Intercept & $-7.83 * * *$ \\
\hline & & Intercept and Trend & $-7.76 * * *$ \\
\hline \multirow[t]{2}{*}{ INF } & \multirow{2}{*}{0.05} & Intercept & $-6.27 * * *$ \\
\hline & & Intercept and Trend & $-6.14 * * *$ \\
\hline \multirow[t]{2}{*}{ NS (Millions) } & \multirow{2}{*}{600.48} & Intercept & $-7-37 * * *$ \\
\hline & & Intercept and Trend & $-7.16^{* * *}$ \\
\hline \multirow[t]{2}{*}{ GDP Growth } & \multirow{2}{*}{0.05} & Intercept & $-10.77 * * *$ \\
\hline & & Intercept and Trend & $-10.56^{* * *}$ \\
\hline \multirow[t]{2}{*}{ ER } & \multirow{2}{*}{0.60} & Intercept & $-3.67 * * *$ \\
\hline & & Intercept and Trend & $-4.04 * * *$ \\
\hline
\end{tabular}
i.e., non-stationarity. The test indicates that all our variables are non-stationarity. However, by taking the first differences all variables become stationary i.e., integrated of order one.

Table 2. Descriptive statistics and augmented Dickey-Fuller

Table 3 reports the results of Vector Autoregressive Regressions. VAR estimation is used to check for short-term causality between FMD and FDI. Therefore, the test is conducted twice, the first one for SMD and the second for BSD. The results of VAR estimation indicate a positive and significant relationship between FDI and SMD in the short-term, however, when the VAR estimation is conducted between FDI and BSD no significant relationship is found between the two variables in the short-term (Note 3).

Based on the VAR results, Table 4 presents the Granger-Causality Tests. In this test, the null hypothesis is that each variable does not Granger Cause the other variable. The results in table 4 suggest that we cannot reject the first null hypothesis, that FDI does not Granger Cause SMD. However, the test shows that the second null hypothesis is rejected where the p-value is 0.013 . For the first proxy, i.e., SMD, the findings document unidirectional effect 
between SMD and FDI. For the second proxy; BSD, both null hypotheses are accepted indicating no causal effect between BSD and FDI. Our results are consistent with Al Nasser and Soydemir (2010) who document similar effects for 14 Latin American countries. The authors argue that a well-developed stock market is an essential determinant of FDI inflows.

Table 3. VAR estimation for SMD

\begin{tabular}{|c|c|c|c|c|c|c|}
\hline Variable & SMD & FDI & GDP & INF & NS & ER \\
\hline \multirow[t]{2}{*}{$\mathrm{SMD}_{\mathrm{t}-1}$} & 0.850 & 0.253 & 0.010 & 0.074 & -0.006 & 0.021 \\
\hline & 0.000 & 0.034 & 0.905 & 0.288 & 0.919 & 0.025 \\
\hline \multirow[t]{2}{*}{$\mathrm{SMD}_{\mathrm{t}-2}$} & -0.148 & 0.316 & -0.071 & 0.132 & -0.070 & 0.003 \\
\hline & 0.365 & 0.003 & 0.347 & 0.037 & 0.227 & 0.690 \\
\hline \multirow[t]{2}{*}{$\mathrm{FDI}_{\mathrm{t}-1}$} & 0.137 & 0.456 & -0.002 & 0.174 & -0.066 & -0.004 \\
\hline & 0.526 & 0.001 & 0.983 & 0.038 & 0.391 & 0.666 \\
\hline \multirow[t]{2}{*}{$\mathrm{FDI}_{\mathrm{t}-2}$} & -0.123 & 0.297 & 0.018 & -0.216 & 0.147 & -0.008 \\
\hline & 0.551 & 0.030 & 0.945 & 0.007 & 0.046 & 0.449 \\
\hline \multirow[t]{2}{*}{$\mathrm{GDP}_{\mathrm{t}-1}$} & 0.292 & -0.253 & 0.286 & -0.084 & 0.182 & -0.046 \\
\hline & 0.462 & 0.335 & 0.123 & 0.583 & 0.201 & 0.025 \\
\hline \multirow[t]{2}{*}{$\mathrm{GDP}_{\mathrm{t}-2}$} & -0.376 & -0.352 & 0.456 & 0.008 & 0.392 & -0.048 \\
\hline & 0.568 & 0.131 & 0.006 & 0.952 & 0.002 & 0.009 \\
\hline \multirow[t]{2}{*}{$\mathrm{INF}_{\mathrm{t}-1}$} & 1.310 & 0.386 & 0.144 & 0.563 & 0.010 & -0.002 \\
\hline & 0.001 & 0.151 & 0.447 & 0.000 & 0.943 & 0.903 \\
\hline \multirow[t]{2}{*}{$\mathrm{INF}_{\mathrm{t}-2}$} & -0.851 & 0.125 & -0.033 & -0.326 & 0.030 & -0.038 \\
\hline & 0.019 & 0.599 & 0.844 & 0.020 & 0.814 & 0.041 \\
\hline \multirow[t]{2}{*}{$N S_{t-1}$} & -0.736 & 0.497 & -0.552 & -0.070 & 0.288 & 0.058 \\
\hline & 0.110 & 0.102 & 0.010 & 0.690 & 0.080 & 0.015 \\
\hline \multirow[t]{2}{*}{$\mathrm{NS}_{\mathrm{t}-2}$} & 0.770 & 0.403 & 0.107 & -0.051 & -0.133 & -0.022 \\
\hline & 0.066 & 0.144 & 0.583 & 0.748 & 0.372 & 0.304 \\
\hline \multirow[t]{2}{*}{$\overline{\mathrm{ER}_{\mathrm{t}-1}}$} & -5.619 & -4.544 & -2.017 & 0.146 & 0.074 & 1.066 \\
\hline & 0.062 & 0.022 & 0.152 & 0.900 & 0.945 & 0.000 \\
\hline \multirow[t]{2}{*}{$\mathrm{ER}_{\mathrm{t}-2}$} & 6.195 & 5.144 & 2.700 & -1.423 & 0.904 & -0.298 \\
\hline & 0.030 & 0.006 & 0.043 & 0.198 & 0.376 & 0.046 \\
\hline$\overline{\mathbf{R}^{2}}$ & 0.78 & 0.88 & 0.41 & 0.86 & 0.60 & 0.89 \\
\hline
\end{tabular}

Table 4. Granger-Causality tests

\begin{tabular}{lll}
\hline Null Hypothesis & Chi-sq & Prob. \\
\hline FDI does not Granger Cause SMD & 0.433 & 0.805 \\
\hline SMD does not Granger Cause FDI & 8.76 & 0.013 \\
\hline FDI does not Granger Cause BSD & 0.44 & 0.799 \\
\hline BSD does not Granger Cause FDI & 0.68 & 0.709 \\
\hline
\end{tabular}

The next step is to test whether the study variables are co-integrated i.e., a long-run equilibrium relationship exists between variables. Co-integration is tested using Johansen co-integration test. Table 5 reports the Johansen System 
Co-integration Test between SMD and FDI. Based on the Trace Statistic and Max-Eigen Statistic the two variables are co-integrated. The p-values are highly significant at $1 \%$ significance level suggesting a long-run relationship does exist between SMD and FDI. Table 6 reports the findings for the second proxy i.e., BSD. The results strongly document a long-run equilibrium relationship between BSD and FDI. Taken together, the results in Table 5 and Table 6 support the existence of a long-run relationship between FMD and FDI. These findings are in line with prior studies (Barrell \&Pain, 1997; Nunnenkamp \& Spatz, 2004; Li \& Liu, 2005; Adam \& Tweneboah, 2008; Abdul Malik \& Amjad, 2013; Tsagkanos et.al, 2018).

Table 5. Johansen system co-integration test between SMD and FDI

\begin{tabular}{lllll}
\hline Hypothesized No. of CE(s) & Eigenvalue & Trace Statistic & Critical Value & Prob \\
\hline None & 0.5002 & 43.4052 & 15.4947 & 0.0004 \\
\hline At most 1 & 0.36149 & 17.0478 & 3.84146 & 0.0000 \\
\hline Hypothesized No. of CE(s) & Eigenvalue & Max-Eigen Statistic & Critical Value & Prob \\
\hline None & 0.7711 & 26.3573 & 14.2646 & 0.0004 \\
\hline At most 1 & 0.1746 & 17.0478 & 3.84146 & 0.0000 \\
\hline
\end{tabular}

Table 6. Johansen system cointegration test between BSD and FDI

\begin{tabular}{lllll}
\hline Hypothesized No. of CE(s) & Eigenvalue & Trace Statistic & Critical Value & Prob \\
\hline None & 0.47721 & 34.2069 & 15.4947 & 0.0008 \\
\hline At most 1 & 0.22244 & 9.56087 & 3.84146 & 0.0002 \\
\hline Hypothesized No. of CE(s) & Eigenvalue & Max-Eigen Statistic & Critical Value & Prob \\
\hline None & 0.47721 & 24.6460 & 14.2646 & 0.0008 \\
\hline At most 1 & 0.22244 & 9.56087 & 3.84146 & 0.0002 \\
\hline
\end{tabular}

Our results indicate that on the short-run a causal effect does exist between SMD and FDI but not between BSD and FDI. These results may be explained as in the short-run the development in the stock market initially attracts FDI. A well-developed market is viewed as an attractive opportunity, particularly with high liquidity and low cost of capital (Tsagkanos et al., 2018). Further, our results are in line with the arguments of Levine (1991), Claessens et.al (2001) and Yartey (2008) who attest that a strong and sound financial market is an important factor in attracting a higher level of FDI. Accordingly, a higher level of FDI raises the market capitalization of the domestic equity market, and enhances the involvement of companies in the financial market. Moreover, this development in the financial market as attracting more FDI, fosters the development in the banking sector development. These arguments are in line with the long-run equilibrium relationship reported in Tables 5 and 6.

\section{Conclusion}

This study examines the dynamic effect between foreign direct investment and financial market development in Jordan. The study employs annual time series data for the period 1978-2017. Financial market development is reflected by two indices, stock market development and banking sector development. Principal component analysis is used to create those indices based on several factors reflecting the development in both the banking sector and stock market. The findings of Vector Autoregressive Regressions (VAR) indicate a positive significant relationship between SMD and FDI, but an insignificant relationship between BSD and FDI in the short-run. The Granger Causality test documents a unidirectional effect from SMD to FDI. Further, using the Johansen co-integration test, the findings reveal that FMD and FDI are co-integrated i.e., have a long-run equilibrium relationship.

These results have important implications for policymakers. With respect to the stock market development, the results suggest the importance of this factor in determining the FDI level, which in turn promotes economic growth, therefore indicating the need for greater attention being focused on stock market development. These developments might be related to the prevailing rules and regulations that facilitate raising capital, which is essential for investment opportunities, highly significant actions that may be required to strengthen the structure and functioning of such 
markets. Regarding the banking sector development, this study illustrates the importance of this variable in the long-run. Policymakers should focus on removing all barriers currently reducing accessibility to the banking sector. Furthermore, policy makers should make financial inclusion a priority to ensure greater accessibility to the banking system services.

\section{References}

Adam, M. A., \& Tweneboah, G. (2008, December 7). Foreign Direct Investment and Stock market Development: Ghana's Evidence MPRA Paper, No. 11985, UTC. Retrieved from https://mpra.ub.uni-muenchen.de/11985/

Al Nasser, O. M., \& Soydemir, G. (2010). Domestic and International Determinants of Foreign Direct Investment in Latin America. FMA Annual Meeting, New York, USA.

Alfaro, A., Chanda, A., Ozcan, S. K., \& Sayek, S. (2010). Does foreign direct investment promote growth? Exploring the role of financial markets on linkages. Journal of Development Economics, 91(2), 242-256. https://doi.org/10.1016/j.jdeveco.2009.09.004

Banos, J. L., Crouzille, C. M., Nys, E., \& Sauviat, A. (2011). Banking industry structure and economic activities: A regional approach for the Philippines. Philippines Management Review, 18(1), 97-113.

Barrell, R., \& Pain, N. (1997). Foreign direct investment, technological change and economic growth within Europe. The Economic Journal, 107(445), 1770-1786. https://doi.org/10.1111/j.1468-0297.1997.tb00081.x

Bekaert, G., Harvey, C. R., \& Lundblad, C. (2004). Does Financial Liberalization Spur Growth?. NBB Working Paper, No. 53, National Bank of Belgium, Brussels. Retrieved from http://hdl.handle.net/10419/144267

Boubakari, A., \& Jin, D. (2010). The role of stock market development in economic growth: evidence from some Euronext countries. International Journal of Financial Research, 1(1), 14-20. https://doi.org/10.5430/ijfr.v1n1p14

Chen, T. J. (1992). Determinants of Taiwan's direct foreign investment: the case of a newly industrializing country. Journal of Development Economics, 39(2), 397-407. https://doi.org/10.1016/0304-3878(92)90046-C

Cheng, S. Y. (2012). Substitution or complementary effects between banking and stock markets: Evidence from financial openness in Taiwan. Journal of International Financial Markets Institutions and Money, 22(3), 508-520. http://doi.org/10.1016/j.intfin.2012.01.007

Cherif, M., \& Dreger, C. (2014, November). Institutional Determinants of Financial Development in MENA Countries. DIW Berlin Discussion Paper, No. 1422. http://doi.org/10.2139/ssrn.2519081

Claessens, S., \& Rhee, M. W. (1993). The effect of equity barriers on foreign investment in developing countries. NBER Working Paper, No. 8087. https://doi.org/10.3386/w4579

Claessens, S., Klingebiel, D., \& Schmukler, S. L. (2001). FDI and stock market development: complements or substitutes?. Mimeo. Retrieved from www.iadb.org/res/publications

Cooray, A. (2010). Do stock markets lead to economic growth?. Journal of Policy Modeling, 32(4), 448-460. https://doi.org/10.1016/j.jpolmod.2010.05.001

Darrat, A. F., Elkhal, K., \& McCallum, B. (2006). Finance and macroeconomic performance: Some evidence from emerging markets. Emerging Markets Finance and Trade, 42(3), 5-28. https://doi.org/10.2753/REE1540-496X420301

Desai, M. A., Foley, C. F., \& Hines, J. R. Jr. (2006). Capital Controls, Liberalizations, and Foreign Direct Investment. The Review of Financial Studies, 19(4), 1433-1464. https://doi.org/10.1093/rfs/hhj041

Domarchi Veliz, F. P., \& Nkengapa, D. L. (2007). FDI and economic growth: a study of 7 transition economies of the CEE and the Baltic states. Doctoral dissertation, Jo"nko"ping University.

Gregorio, D. J., \& Guidotti, P. E. (1995). Financial development and economic growth. World Development, 23(3), 433-448. https://doi.org/10.1016/0305-750X(94)00132-I

Gries, T., Kraft, M., \& Meierrieks, D. (2009). Linkages between financial deepening, trade openness, and economic development: Causality evidence from sub-Saharan Africa. World Development, 37(12), 1849-1860. https://doi.org/10.1016/j.worlddev.2009.05.008

Hermes, N., \& Lensink, R. (2003). Foreign direct investment, financial development and economic growth. Journal of Development Studies, 40(1), 142-163. http://doi.org/10.1080/00220380412331293707 
Hou, H., \& Cheng, S. Y. (2010). The roles of stock market in the finance-growth nexus: Time series cointegration and causality evidence from Taiwan. Applied Financial Economics, 20(12), 975-981. http://doi.org/10.1080/09603101003724331

Ihtisham, A. M., \& Amjad, S. (2013). Foreign direct investment and stock market development in Pakistan. Journal of International Trade Law and Policy, 12(3), 226-24. https://doi.org/10.1108/JITLP-02-2013-0002

Issouf, S., \& Fulbert, T. (2011). Causality between FDI and Financial Market Development: Evidence from Emerging Markets. MPRA Paper, No. 31328.

Jeffus, M. W. (2004). FDI and Stock Market Development in Selected Latin Downloaded by University of New England (AUS) At 11:44 20 November 2018 (PT) American Countries. International Finance Review, 5, 35-44. http://doi.org/10.1016/S1569-3767(05)05003-X

Johansen, S. (1988). Statistical analysis of cointegration vectors. Journal of Economic Dynamics and Control, 12(2-3), 231-254. https://doi.org/10.1016/0165-1889(88)90041-3

Kar, M., Nazlioglu, S., \& Agir, H. (2011). Financial development and economic growth nexus in the MENA countries: Bootstrap panel granger causality analysis. Economic Modelling, 28(1-2), 685-693. https://doi.org/10.1016/j.econmod.2010.05.015

Kolapo, F. T., \& Adaramola, A. O. (2012). The impact of the Nigerian capital market on economic growth (1990-2010). International Journal of Developing Societies, $1(1), \quad 11-19$. https://doi.org/10.1080/09765239.2012.11884948

Korgaonkar, C. (2012). Analysis of the impact of financial development on foreign direct investment: a data mining approach. Journal of Economics and Sustainable Development, 3(6), 70-78.

Levine, R. (1991). Stock markets, growth, and tax policy. Journal of Finance, 46(4), 1445-1465. https://doi.org/10.1111/j.1540-6261.1991.tb04625.x

Levine, R., \& Zervos, S. (1996). Stock market development and economic growth. World Bank Economic Review, 1, 323-340. https://doi.org/10.1093/wber/10.2.323

Levine, R., Loayza, N., \& Beck, T. (2000). Financial intermediation and growth: Causality analysis and causes. Journal of Monetary Economics, 46(1), 31-77. https://doi.org/10.1016/S0304-3932(00)00017-9

Li, X., \& Liu, X. (2005). Foreign direct investment and economic growth: an increasingly endogenous relationship. World Development, 33, 393-407. https://doi.org/10.1016/j.worlddev.2004.11.001

Malcu, M., \& Persson, M. (2018). The Impact of direct foreign investment on the stock market development in Sweden. Thesis, University of Gothenburg, School of Business, Economics and Law. Retrieved from http://hdl.handle.net/2077/55463

Markowitz, H. (1952). Portfolio Selection. The Journal of Finance, 7(1), 77-91. https://doi.org/10.1111/j.1540-6261.1952.tb01525.x

Mishal, Z., \& Abulaila, Z. (2007). The Impact of Foreign Direct Investment and Imports on Economic Growth: The Case of Jordan. Journal of Economic and Administrative Sciences, 23(1), 1-31. https://doi.org/10.1108/10264116200700001

Naceur, S. B., \&Ghazouani, S. (2007). Stock markets, banks, and economic growth: Empirical evidence from the MENA region. Research in International Business and Finance, 21(2), 297-315. https://doi.org/10.1016/j.ribaf.2006.05.002

Nazir, M. S., Nawaz, M. M., Anwar, W., \& Ahmed, F. (2010). Determinants of stock price volatility in Karachi stock exchange: the mediating role of corporate dividend policy. International Research Journal of Finance and Economics, 55.

Nunnenkamp, P., \& Spatz, J. (2004). FDI and economic growth in developing economies: how relevant are host-economy and industry characteristics. Transnational Corporations, 13(3), 53-86.

OECD. (2008). Handbook on constructing composite indicators: Methodology and user guide. Paris: OECD Publishing, Organization for Economic Co-operation and Development.

Pradhan, R. P. (2010). Financial Deepening, Foreign Direct Investment and Economic Growth: Are They Cointegrated. International Journal of Financial Research, 1(1). https://doi.org/10.5430/ijfr.v1n1p37 
Pradhan, R. P., Arvin, M. B., Bele, S., \& Taneja, S. (2013). The impact of stock market development on inflation and economic growth of 16 Asian countries: A panel VAR approach. Applied Econometrics and International Development, 13(1), 203-220.

Pradhan, R. P., Arvin, M. B., Hall, J. H., \& Bahmani, S. (2014). Causal nexus between economic growth, banking sector development, stock market development, and other macroeconomic variables: The case of ASEAN countries. Review of Financial Economics, 23(4), 155-173. https://doi.org/10.1016/j.rfe.2014.07.002

Pradhan, R. P., Dasgupta, P., \& Bele, S. (2013). Finance, development and economic growth in BRICS: A panel data analysis. Journal of Quantitative Economics, 11(1-2), 308-322.

Raza, S. A., Jawaid, S. T., Afshan, S., \& Abd Karim, M. Z. (2015). Is stock market sensitive to foreign capital inflows and economic growth? Evidence from Pakistan. Journal of Chinese Economic and Foreign Trade Studies, 8(3), 142-164. https://doi.org/10.1108/JCEFTS-03-2015-0012

Sultana, T. S., \& Pardhasaradhi, S. (2012). Impact of Flow of FDI \& FII on Indian Stock Market. Finance Research, 1(3), 4-10.

Tsagkanos, A., Siriopoulos, C., \& Vartholomatou, K. (2019). Foreign direct investment and stock market development: Evidence from a new emerging market. Journal of Economic Studies, 46(1), 55-70. https://doi.org/10.1108/JES-06-2017-0154

Yartey, C. A. (2008). The determinants of stock market development in emerging economies: Is South Africa different. IMF working paper, No. WP/08/32 (pp. 1-31). https://doi.org/10.5089/9781451868944.001

Zvi, B., Alex, K., \& Alan, M. (2014). Investments (10th ed.). Yew York: McGraw-Hill.

\section{Notes}

Note 1. To access this database follow this link: https://unctadstat.unctad.org/wds/TableViewer/tableView.aspx

Note 2. See Pradhan et al., (2014) for similar methodology.

Note 3. The VAR estimation results for BSD are unreported but available upon request. 